\title{
When an Easy Thing Goes Wrong: Foreign Body Induced Granuloma-Associated Scleritis Following Pterygium Surgery
}

\author{
Pedro Coelho Carlos Menezes Pedro Rodrigues Rita Gonçalves \\ Tiago Maio Jorge Moreira Paula Tenedório \\ Department of Ophthalmology, Hospital Pedro Hispano, Matosinhos, Portugal
}

\section{Keywords}

Pterygium surgery · Iatrogenic scleritis · Anterior scleritis · Amniotic membrane

\begin{abstract}
Purpose: To report a case of pterygium surgery with conjunctival autograft followed by focal necrotizing scleritis due to foreign body entrapment in the scleral bed. Case Report/Results: This is a case report of a 76-years-old male patient who underwent nasal pterygium surgery and developed focal necrotizing scleritis secondary to foreign body entrapment under conjunctival autograft. One month following surgery, slit-lamp examination demonstrated a progressive thinning of the surgical area with focal inflammatory signs. A small synthetic fiber was identified to be trapped under the graft. A second intervention was performed with foreign body removal and a new conjunctival graft. Despite the surgery, focal scleral melting continued to progress and the patient was placed under systemic corticotherapy and submitted to amniotic membrane graft with epithelial side up. During the follow-up period there was a good tissue response. Conclusion: Despite being a safe and quick procedure, pterygium surgery can sometimes elicit new challenges.

(C) 2017 The Author(s) Published by S. Karger AG, Basel
\end{abstract}

\section{Introduction}

Nowadays, pterygium surgery with simple excision, or bare sclera surgery, is no longer recommended due to high recurrence rates. Excision followed by anatomical reconstruction 
with conjunctival autograft is currently the mainstay therapy. It is considered a safe procedure, with a quick learning curve and is performed in a short period of time, with serious complications being very rare [1]. Necrotizing anterior scleritis is a serious threat to the integrity of the eye and can occur following a surgical procedure where the sclera has been dissected and cauterized, such as filtering surgery in glaucoma and pterygium surgery. It may also be associated with a granulomatous response to a scleral foreign body [2].

\section{Case Report and Results}

This is a retrospective chart review of a patient who developed a foreign body granuloma-associated scleritis following pterygium surgery with autologous conjunctival graft due to synthetic fiber entrapment underneath the graft.

A 76-year-old male with a nasal pterygium was submitted to excision followed by autologous conjunctival graft harvested from the superior bulbar conjunctiva and applied with fibrin glue (Tissucol ${ }^{\circledR}$ ). There were no intraoperative complications. A fixed combination of gentamicin $(3 \mathrm{mg} / \mathrm{mL})$ plus dexamethasone $(1 \mathrm{mg} / \mathrm{mL})$ drops 6 times a day was prescribed in the first 2 weeks after the procedure, followed by gradual weaning. One week after surgery, the expected inflammation and chemosis were observed, with the graft being well positioned anatomically. The patient was then rescheduled for an appointment 1 month after surgery. At this time, slit-lamp examination demonstrated an epithelial defect with focal thinning and whitening of the conjunctival flap and sclera underneath associated with hyperemia and sentinel vessels surrounding the area (Fig. 1). The only complaints referred were foreign body sensation and slight discomfort. Remaining ocular examination was unremarkable, with best-corrected visual acuity of 20/20, and no signs of intraocular inflammation. A white synthetic fiber from the surgical field was identified, trapped between the graft and the sclera.

After 3 days, a second surgical intervention was performed, with removal of the foreign body, debridement of the necrotic material, and reconstruction with a new $3 \times 3 \mathrm{~mm}$ conjunctival graft applied with fibrin glue. Four days after surgery we observed that focal tissue melting with consumption of the graft continued to occur. The patient was admitted to our department and started oral prednisolone $1 \mathrm{mg} / \mathrm{kg}$ per day, maintained until amniotic membrane (AM) graft was performed 4 days later. Scleral and systemic workup was performed to exclude autoimmune and infectious causes.

The AM was placed over the scleral melting in a sandwich technique, with 2 layers placed with stromal side down, and another one with epithelium facing down. AM was secured with 8/0 absorbable sutures (Fig. 2). Oral prednisolone was continued and tapered on a weekly basis, along with topical antibiotic. One week after surgery, slit-lamp examination revealed AM integration with decrease of scleral vascularization and interruption of the scleral melting. In week 3 there was complete integration of the AM, with no epithelial defect or signs of active inflammation (Fig. 3). Histological examination of the excised tissue revealed giant cells and necrosis consistent with foreign body granuloma.

\section{Discussion}

We presented a case of foreign body granuloma-associated scleritis. The innate unspecific immunologic response associated with the synthetic fiber in a high vascularized or in- 
flamed tissue, such as the surgical site following pterygium surgery, led to focal scleral melting that persisted after the foreign body had been removed.

Additionally to the surgical approach, immunosuppressive chemotherapy is frequently required to arrest the necrotizing process in surgical-induced scleritis. Systemic corticosteroids, cyclophosphamide, and methotrexate are frequently used as first-line immunosuppressive agents $[3,4]$.

Our patient demonstrated a good clinical response following systemic corticotherapy and AM graft. AM was used as a graft in order to exert a local anti-inflammatory response and reconstruct the melted tissue. Some published reports demonstrate the clinical utility of AM when addressing surgical-induced scleritis [5, 6].

AM is widely used when approaching ocular surface disease, such as persistent epithelial defect of the cornea or ocular surface chemical burns, among others. This is due to AM's intrinsic characteristics, promoting anti-inflammatory and anti-fibrotic effects, and the existing growth factors that induce epithelial wound healing [7]. Besides that, AM is easily available, has low immunologic rejection, and has a nonantigenic nature. Anatomic orientation of the AM is important according to the intended purpose. To create a graft, AM should be placed with epithelial side up. If the goal is to patch, then the epithelial side of the membrane should be placed in contact with the ocular surface [7]. Despite the orientation, the antiinflammatory properties of the AM are preserved. AM is associated with decrease of proinflammatory cytokines (IL-1), inhibition of metalloproteases, and sequestration of inflammatory cells with apoptosis in the membrane itself [8]. When used as a graft, it promotes repopulation of the amnion stroma with corneal stroma-derived cells, which allows for scleral integrity [9]. We used a multilayer approach in order to additionally create a fill-in effect.

In conclusion, AM graft demonstrated to be a good therapeutic option in stopping the scleral melting associated with a foreign body. This case illustrates the unpredictable risks hidden in a simple ophthalmological procedure.

\section{Statement of Ethics}

Patient consent and Hospital Ethics Committee approval were obtained.

\section{Disclosure Statement}

The authors have no conflicts of interest.

\section{References}

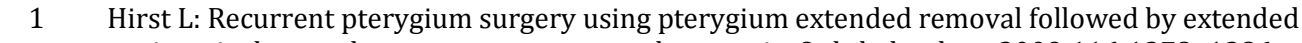
conjunctival transplant: recurrence rate and cosmesis. Ophthalmology 2009;116:1278-1286.

2 Foster CS, Sainz de la Maza M: The Sclera. New York, Springer, 1994, pp 205-227.

-3 Das S, Saurabh K, Biswas J: Postoperative necrotizing scleritis: a report of four cases. Middle East Afr J Ophthalmol 2014;21:350-353.

4 Young AL, Wong SM, Leung AT, Leung GY, Cheng LL, Lam DS: Successful treatment of surgically induced necrotizing scleritis with tacrolimus. Clin Experiment Ophthalmol 2005;33:98-99.

5 Karalezli A, Kucukerdonmez C, Borazan M, Akova YA: Successful treatment of necrotizing scleritis after conjunctival autografting for pterygium with amniotic membrane transplantation. Orbit 2010;29:8890. 


\section{Case Reports in Ophthalmology}

\begin{tabular}{l|l}
\hline Case Rep Ophthalmol 2017;8:195-199 \\
\hline DOI: 10.1159/000464402 & $\begin{array}{l}\text { C } 2017 \text { The Author(s). Published by S. Karger AG, Basel } \\
\text { www.karger.com/cop }\end{array}$ \\
\hline
\end{tabular}

Coelho et al.: When an Easy Thing Goes Wrong: Foreign Body Induced GranulomaAssociated Scleritis Following Pterygium Surgery

-6 Pararda-Vásquez RH, Benítez-Castrillón PC, de León-Ortega JE, León-Roldán CR: Parche escleral en manejo de escleritis necrosante con inflamación. Informe de un caso. Arch Soc Esp Oftalmol 2015;91:353-354.

7 Dua HS, Gomes JAP, Singh A: Corneal epithelial wound healing. Br J Ophthalmol.1994;8:401-407.

-8 Tosi GM, Massaro-Giordano M, Caporossi A, Toti P: Amniotic membrane transplantation in ocular surface disorders. J Cell Physiol 2005;202:849-851.

9 Said DG, Nubile M, Alomar T, Hopkinson A, Gray T, Lowe J, Dua HS: Histologic features of transplanted amniotic membrane: implications for corneal wound healing. Ophthalmology 2009;116:1287-1295.

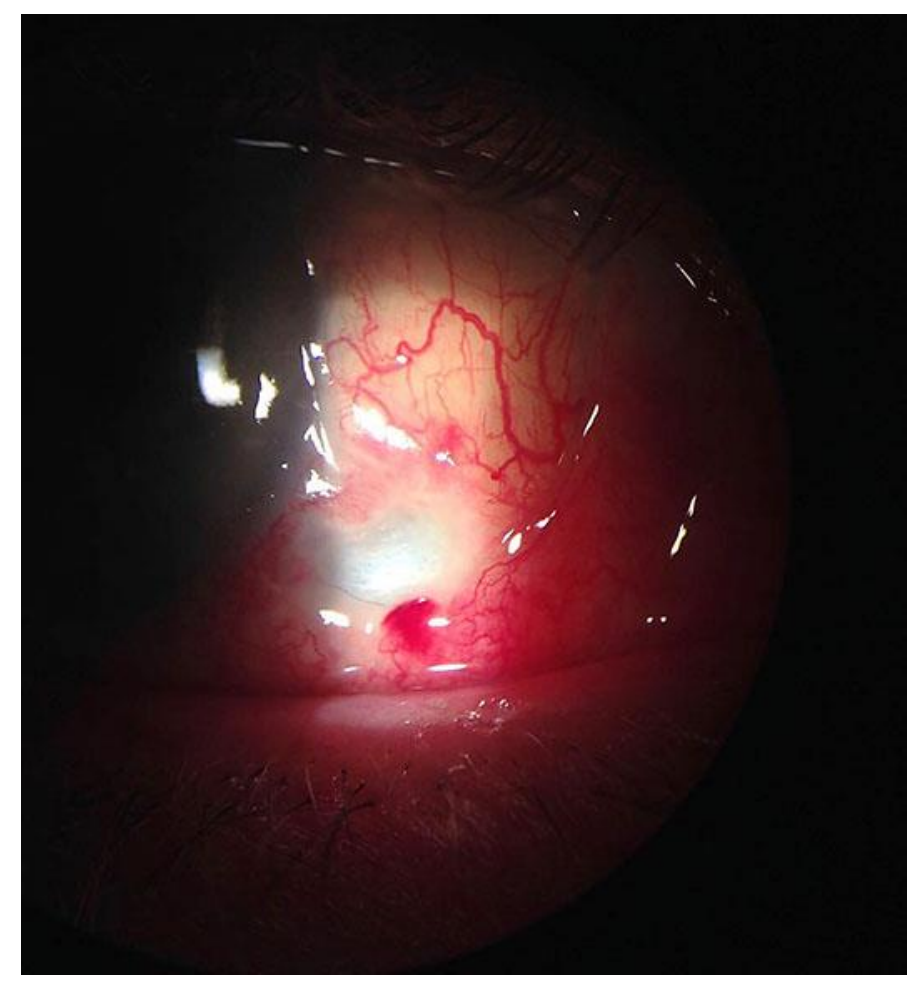

Fig. 1. Scleral melting 1 month after pterygium surgery. 


\section{Case Reports in Ophthalmology}

\begin{tabular}{l|l}
\hline Case Rep Ophthalmol 2017;8:195-199 \\
\hline DOI: 10.1159/000464402 & $\begin{array}{l}\text { C } 2017 \text { The Author(s). Published by S. Karger AG, Basel } \\
\text { www.karger.com/cop }\end{array}$ \\
\hline
\end{tabular}

Coelho et al: When an Easy Thing Goes Wrong: Foreign Body Induced GranulomaAssociated Scleritis Following Pterygium Surgery

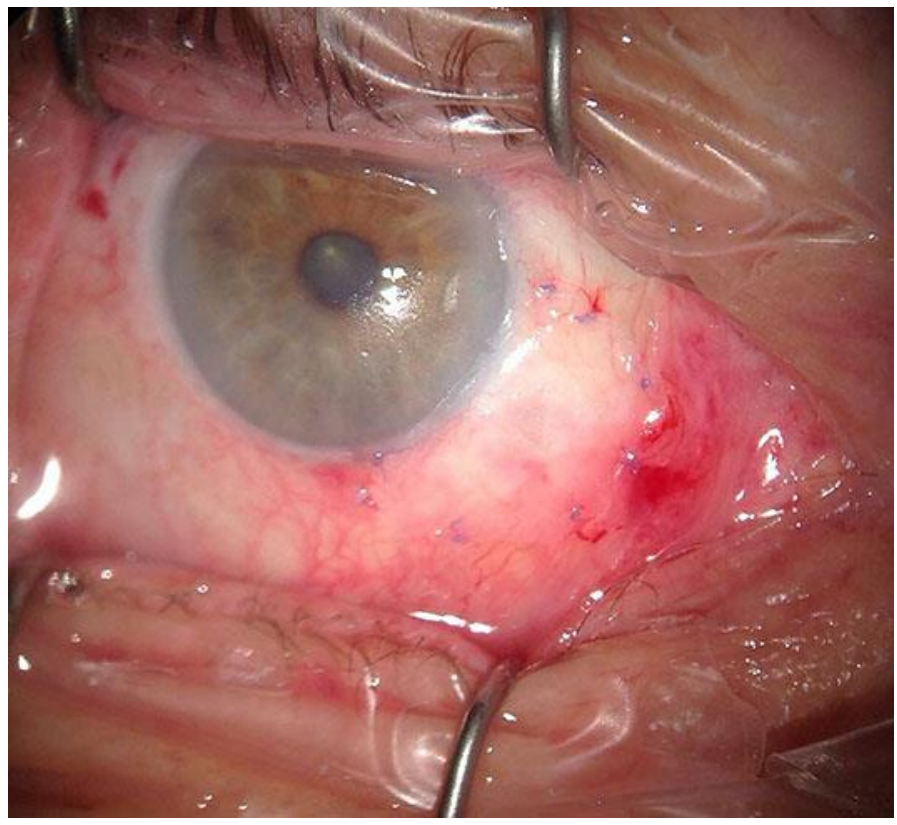

Fig. 2. Amniotic membrane graft in place secured with absorbable sutures.

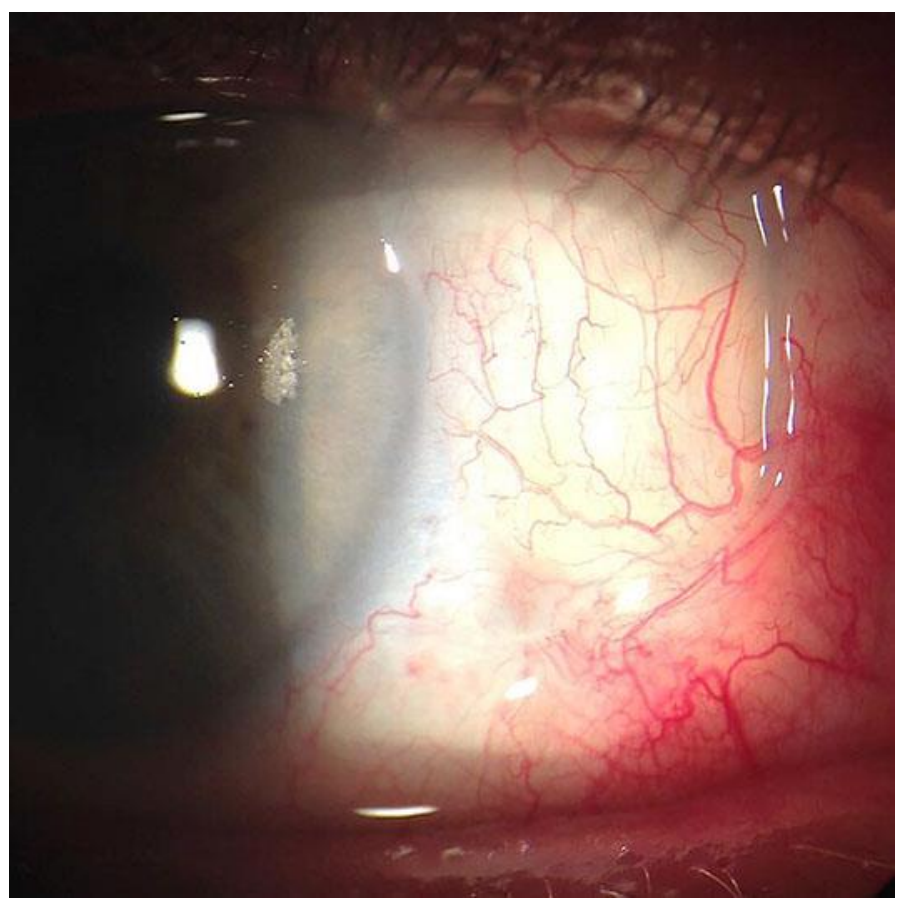

Fig. 3. Three weeks following amniotic membrane (AM) graft: complete AM integration and local inflammation resolved. 